\title{
ANALISA VARIASI HARMONIK PASANG SURUT DI PERAIRAN SURABAYA AKIBAT FENOMENA EL-NINO
}

\author{
Bangun Muljo Sukojo ${ }^{1}$, Iva Ayu Rinjani ${ }^{1}$ \\ ${ }^{1}$ Departemen Teknik Geomatika, FTSLK-ITS, Kampus ITS Sukolilo, Surabaya, 60111, Indonesia \\ e-mail: ${ }^{1}$ bangun_ms@geodesy.its.ac.id
}

\begin{abstract}
Abstrak
Pengaruh fenomena El Nino juga dapat dipelajari dan dianalisis menggunakan data fluktuasi pasang surut di permukaan laut. Pasang surut adalah naik turunnya permukaan laut disebabkan oleh kombinasi gaya gravitasi dari rotasi bulan, matahari dan Bumi. Selain itu, perubahan suasana seperti perubahan tekanan, angin dan suhu akan mempengaruhi pola pasang surut dan aktivitas pasang surut. Hasil kajian menunjukan penurunan MSL selama terjadi El Nino di Perairan Surabaya mengikuti persamaan linier dengan persamaan $y=114.1-0.3782 x(R 2=20,69 \%)$ dengan penurunan MSL sebesar 4,347 cm sepanjang 2014-2015.
\end{abstract}

Kata Kunci : El Nino, MSL (Mean Sea Level), SPL (suhu permukaan laut), Surabaya

\begin{abstract}
The influence of the EI Nino phenomenon can also be studied and analyzed using tidal fluctuation data at sea level. Ups and downs are ups and downs of sea level caused by a combination of gravitational forces from the rotation of the moon, sun and Earth. In addition, changes in atmosphere such as changes in pressure, wind and temperature will affect tidal patterns and tidal activity. The results showed that MSL decrease during EI Nino in Surabaya waters followed the linear equation with $y=114.1-0.3782 x(R 2=20,69 \%)$ with MSL decrease 4,347 cm during 2014-2015.
\end{abstract}

Keywords - EI Nino, MSL (Mean Sea Level), SST (Sea Surface Temperature), Surabaya

\section{PENDAHULUAN}

EL Nino adalah suatu gejala penyimpangan kondisi laut yang ditandai dengan meningkatnya suhu permukaan laut (Sea Surface Temperature-SST) di Samudra Pasifik sekitar Equator (Equatorial pacific), khususnya di bagian tengah dan timur (sekitar pantai Peru). Karena lautan dan atmosfer adalah dua sistem yang saling terhubung, maka penyimpangan kondisi laut ini menyebabkan terjadinya penyimpangan pada kondisi atmosfer yang pada akhirnya berakibat pada terjadinya penyimpangan.

Dalam kondisi iklim normal, suhu permukaan laut di sekitar Indonesia (Pasifik Equator bagian barat) umumnya hangat dan karenanya proses penguapan mudah terjadi dan awan-awan hujan mudah terbentuk. Namun ketika fenomena EI Nino terjadi, saat suhu permukaan laut di Pasifik Equator bagian tengah dan timur menghangat, justru perairan sekitar Indonesia umumnya mengalami penurunan suhu (menyimpang dari biasanya). Badan Meteorologi, Klimatologi, dan
Geofisika (BMKG) menyatakan fenomena El Nino diprediksi akan menguat mulai Agustus hingga Desember 2015. Tren penguatan El Nino 2015 ini ditunjukkan oleh kenaikan indeks El Nino Southern Oscillation (ENSO) dari 1,6 pada Juni menjadi 2,2 pada Desember 2015 [2]. Panjangnya musim kemarau di berbagai tempat di Indonesia, terutama di sebelah selatan khatulistiwa diduga merupakan dampak dari fenomena El Nino yang mencapai level sedang. Karena tekanan atmosfer dan suhu laut berkaitan erat, indeks atmosfer disebut Southern Oscillation Index (SOI) digunakan untuk mengukur respon atmosfer. Indeks tersebut dihitung dari perbedaan tekanan udara berfluktuasi bulanan antara Tahiti dan Darwin. SOI telah banyak digunakan untuk mengukur intensitas El Nino seperti Kiladis dan Loon (1988) menggunakan SOI untuk mengukur terjadinya $\mathrm{EI}$ Nino untuk Samudera Pasifik Timur. Selanjutnya, SOI juga digunakan dalam memantau kegiatan El Nino dengan nilai-nilai SOI. Melalui nilai-nilai SOI, 
dapat menentukan puncak dan lemah dari El Nino terjadinya.

Pengaruh fenomena ini juga dapat dipelajari dan dianalisis menggunakan data fluktuasi pasang surut di permukaan laut. Pasang surut adalah naik turunnya permukaan laut disebabkan oleh kombinasi dari Bumi gaya gravitasi dari rotasi bulan, matahari dan Bumi. Selain itu, perubahan suasana seperti perubahan tekanan, angin dan suhu akan mempengaruhi pola pasang surut dan aktivitas pasang surut. Misalnya, sirkulasi angin mempengaruhi terjadinya gelombang laut dan arus laut. Tekanan atmosfer dan curah hujan juga mempengaruhi fluktuasi dari permukaan laut. Pengetahuan parameter meteorologi dan variabel Oceanografi di perairan Indonesia diperlukan untuk memahami karakteristik dinamis dan pasang tinggi, terutama selama dan pemanasan global.

Pembentukan jaringan pasang surut di Indonesia adalah untuk mengamati pasang terus menerus. Ini termasuk pembentukan permukaan laut nilai rata-rata untuk setiap stasiun. Selain itu, pengamatan pasang surut digunakan untuk analisis pasang surut untuk menentukan konstituen pasang surut dan digunakan untuk prediksi. Selain itu, jaringan pasang memainkan peran penting dalam menentukan karakteristik atau perilaku sepanjang pesisir terutama selama perubahan iklim mendadak seperti fenomena El Nino, yang Monsoon Timur Laut, Barat Laut Monsoon dan Tsunami.

Menurut Crawford dkk, pengaruh kekinian dan anomali seperti El Nino mempengaruhi akurasi konstanta pasang surut. Pengaruh tertinggi yang tercatat dikonstanta periode panjang pasang surut adalah karena pengaruh El Nino. Oleh karena itu, penelitian ini dilakukan untuk mengidentifikasi variasi harmonik pasang surut selama terjadi $\mathrm{El}$ Nino. Data yang digunakan adalah data pengamatan pasang surut in situ, data suhu permukaan laut, dan data SOI.

Dalam penelitian ini akan dilakukan bagaimana menentukan variasi harmonik pasang surut laut dan variasi harmonik pasang surut laut selama terjadi El Nino.

Daerah studi pada penelitian ini adalah kawasan perairan Surabaya terkait dengan variasi pasang surut selama terjadinya El Nino dan data pengamatan pasang surut yang digunakan dalam peneltian ini adalah data pengamatan pasang surut sepanjang tahun 2014-2015. Sedangkan metode pengolahan konstanta harmonik pasang surut dilakukan dengan metode least square.

Penelitian ini bertujuan untuk menentukan variasi harmonik pasang surut laut dan untuk mengetahui variasi harmonik pasang surut laut selama terjadi El Nino.

Adapun manfaat yang diharapkan dari program penelitian ini adalah untuk mengetahui pengaruh fenomena El Nino terhadap variasi harmonik pasang surut di kawasan perairan Surabaya.

\section{METODOLOGI PENELITIAN}

Lokasi yang dipilih untuk melakukan penelitian ini adalah di perairan Surabaya, Indonesia. Batasan wilayah penelitian adalah data dari stasiun pasang surut terletak di area Pelabuhan Tanjung Perak Surabaya dengan lokasi koordinat lintang $07^{\circ} 12^{\prime} 0.2^{\prime \prime}$ LS dan bujur $112^{\circ} 44^{\prime} 26,7^{\prime \prime}$ BT.

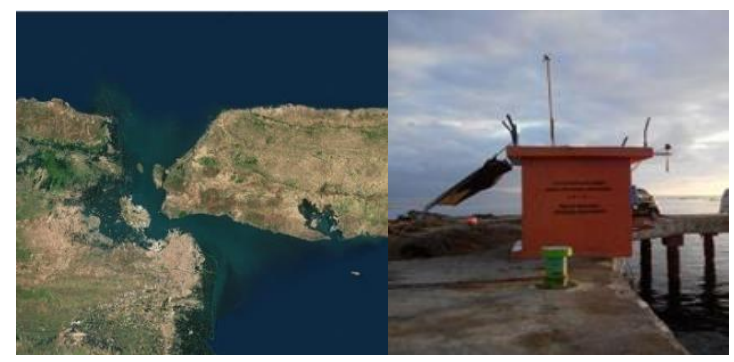

Gambar 1. Perairan Surabaya dan Stasiun pasut Pelabuhan Tanjung Perak (Bakosurtanal, 2015)

Tahapan penelitian ini meliputi :

- Identifikasi terjadinya El Nino menggunakan SOI (standart Oscillation Indeks) dan suhu permukaan laut.

- Referensi yang berhubungan dengan penelitian yang berasal dari buku, penelitian sebelumnya, jurnal, dan sumber lainnya.

- Pengambilan data yang digunakan dalam penelitian ini merupakan data pasang surut dengan pengamatan pasang surut Kawasan Perairan Surabaya tahun (2014-2015) dari Badan Informasi Geospasial (BIG) dan data SOI dan suhu permukaan Laut Surabaya tahun (2014-2015) dari ecmwf. Data citra diunduh dari http://oceancolor.gsfc.nasa.gov/ meliputi citra satelit MODIS level 3 dengan resolusi spasial $4 \mathrm{~km}$, data tersebut telah diolah sehingga telah terkoreksi secara radiometrik 
dan geometrik. Citra yang dipilih adalah data rata-rata bulanan dari Januari 2014 Desember 2015 selama dua tahun terdiri dari citra Aqua MODIS.

Tahapan pengolahan data sebagai berikut ini:

1. Identifikasi terjadi El Nino menggunakan data SOI tahun 2014-2015. Setelah teridentifikasi terjadi El Nino dilakukan pengumpulan data pasang surut, suhu permukaan laut dan data citra.

2. Pengolahan pasang surut menggunakan data pasang surut insitu dari stasiun pasang surut Badan Informasi Geospasial. Data pasang surut ini diproses menggunakan perangkat lunak pengolah angka pasang surut dengan metode least square sebagai analisis pasang surut. Kemudian dibuat grafik MSL bulanan perairan Surabaya.

3. Data citra Aqua MODIS level 3 dengan pilihan format NetCDF (network Common Data Form) dimana data tersebut merupakan data digital compressed, sehingga citra yang ditampilkan sudah menjadi datar (flat). Data yang akan diolah sebelumnya diekstrak terlebih dahulu. Kemudian data suhu permukaan laut dari citra Aqua MODIS ratarata bulanan selama dua tahun.

4. Data suhu permukaan laut dari hasil asimilasi data ecmwf diektrak dan didapatkan suhu permukaan laut Surabaya.

5. Pembuatan grafik data suhu permukaan laut bulanan perairan Surabaya. Kemudian mencari korelasi antara MSL dengan suhu permukaan laut dengan menggunakan persamaan regresi linier.

1. Analisa komponen harmonik pasang surut.

- Analisa Data

Analisa pasang surut digunakan untuk menentukan tingkat air atau pola pasang surut dengan memproduksi amplitudo dan fase. Setiap amplitudo dan fase terdiri dari konstanta pasang surut dimana konstanta menunjukkan jenis tingkat air dan pola pasang surut. Selain itu, konstanta pasang surut yang digunakan dalam pengolahan untuk menghasilkan prediksi pasang surut. Analisa regresi linier.
Untuk pengolahan citra disajikan dalam diagram alir sebagai berikut :

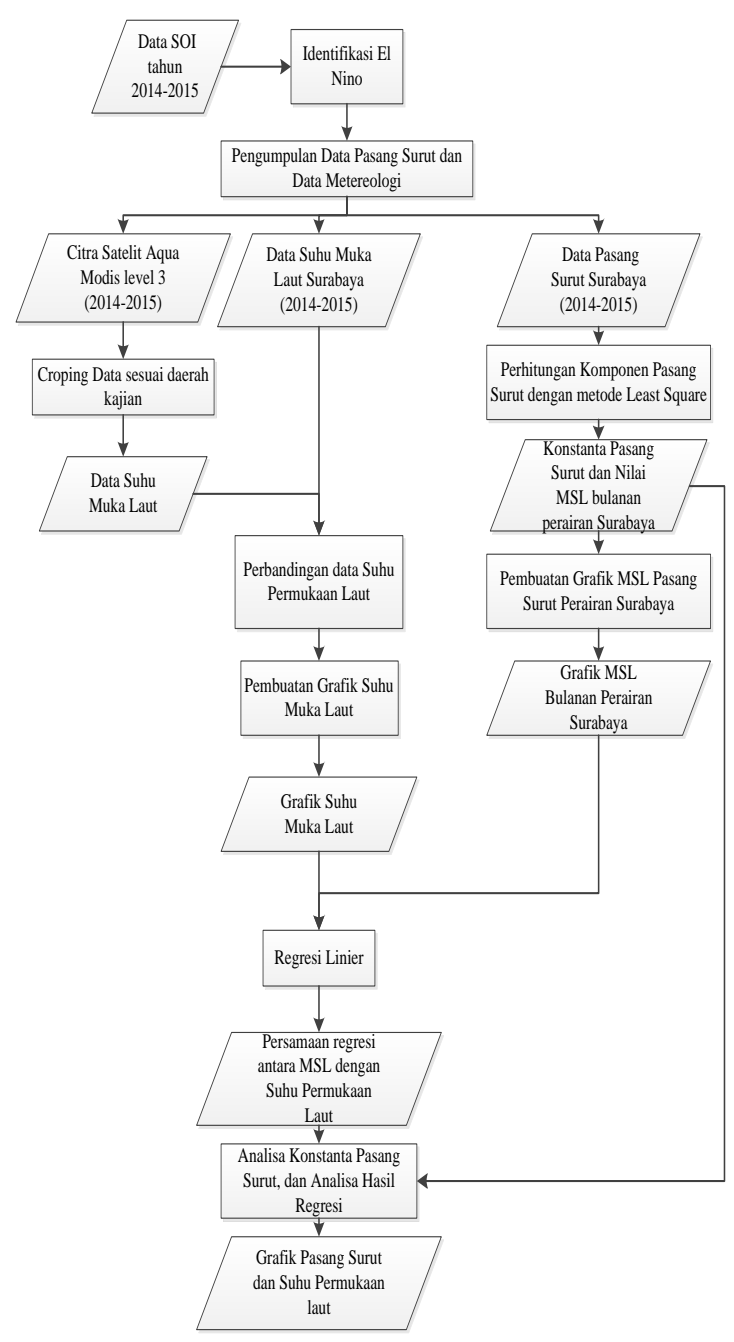

Gambar 2. Diagram Alir Pengolahan Citra

Cara lain yang bisa dilakukan adalah dengan menguraikan dalam bentuk beberapa kalimat untuk bab pengolaha data tersebut.

\section{HASIL DAN PEMBAHASAN}

\section{Identifikasi El Nino}

Identifikasi Standard Oscillation Index (SOI)

Nilai data SOI (standard Oscillation Index) merupakan indek untuk mengetahui seberapa kuat fenomena El-Nino, untuk stasiun pengamatan Nino $3.4\left(5^{\circ} \mathrm{N}-5^{\circ} \mathrm{S}, 120^{\circ}-170^{\circ} \mathrm{W}\right)$ tahun 2014-2015 seperti terlihat pada tabel berikut ini: 
Tabel 1 Nilai SOI Stasiun El Nino 3.4

\begin{tabular}{ccc}
\hline \multirow{2}{*}{ Bulan } & \multicolumn{2}{c}{ Tahun } \\
\cline { 2 - 3 } & 2014 & 2015 \\
\hline Januari & $-0,5$ & 0,5 \\
Februari & $-0,6$ & 0,4 \\
Maret & $-0,4$ & 0,5 \\
April & $-0,2$ & 0,7 \\
Mei & 0 & 0,9 \\
Juni & 0 & 1,0 \\
Juli & 0 & 1,2 \\
Agustus & 0 & 1,5 \\
September & 0,2 & 1,8 \\
Oktober & 0,4 & 2,1 \\
November & 0,6 & 2,2 \\
Desember & 0,6 & 2,3 \\
\hline
\end{tabular}

Dari data pada tabel 4.1 nilai SOI tertinggi pada bulan Desember 2015 dan terendah pada bulan Februari 2014 . Hal ini dapat diidentifikasi bahwa fenomena El Nino mulai tahun 2015 menguat. Berikut ini merupakan grafik tentang nilai SOI yang terjadi pada tahun 20142015:

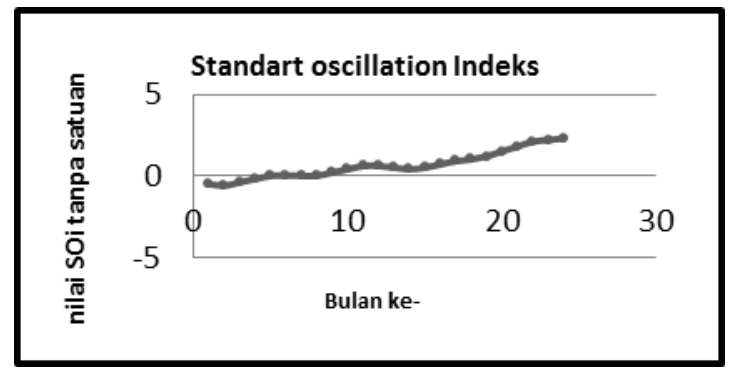

Gambar 3 Grafik tren SOI tahun 2014-2015

Ambang batas SOI terbagi menjadi fenomena El Nino lemah $(0,5-0,9)$, moderate $(1,0-1,4)$, kuat ( $1,5-1,9)$ dan sangat kuat $(\geq 2,0)$. Untuk tujuan laporan ini untuk sebuah event dikategorikan sebagai lemah , sedang, kuat atau sangat kuat itu harus menyamai atau melebihi ambang batas minimal selama 3 bulan berturut-turut (NOAA, 2015).

Pada Gambar 4 dapat ditunjukkan bila terjadi EI Nino menjadi kuat mulai dari bulan Maret 2015. Bahkan pada bulan Oktober 2015 hingga Desember 2015 menjadi sangat kuat.

Hasil Pengolahan Data Suhu Permukaan Laut (SPL)

Selanjutnya dilakukan pengolahan data suhu yang diekstrak dari citra Aqua MODIS Sea Surface Temperature level 3 dengan menggunakan perangkat lunak Seadas koordinat $112^{\circ} 52^{\prime} 30^{\prime \prime}$ BT dan $7^{\circ} 12^{\prime} 30^{\prime \prime}$ LS seperti yang diperlihatkan pada tabel berikut ini:
Tabel 2 Nilai Suhu AQUA MODIS Sea Surface Temperature Level 3 (dalam satuan ${ }^{\circ} \mathrm{C}$ )

\begin{tabular}{ccc}
\hline \multirow{2}{*}{ Bulan } & \multicolumn{2}{c}{ Tahun } \\
\cline { 2 - 3 } & 2014 & 2015 \\
\hline Januari & 29,2 & 30,5 \\
Februari & 29,9 & 30,9 \\
Maret & 31,3 & 30,8 \\
April & 29,2 & 31,6 \\
Mei & 30,7 & 29,7 \\
Juni & 30,2 & 29,4 \\
Juli & 29,4 & 28,3 \\
Agustus & 29,2 & 28,6 \\
September & 28,9 & 29,1 \\
Oktober & 30,3 & 29,2 \\
November & 31,1 & 33,2 \\
Desember & 34,2 & 31,3 \\
\hline
\end{tabular}

Dari Tabel 2 diketahui bila suhu tertinggi $34,2{ }^{\circ} \mathrm{C}$ pada bulan Desember tahun 2014 dan suhu terendah sebesar $28,3^{\circ} \mathrm{C}$ pada bulan Juli tahun 2015 . Sedangkan nilai rata-rata suhunya sebesar $30,3^{\circ} \mathrm{C}$

Selanjutnya untuk pengolahan data suhu asimilasi perairan Surabaya dari Ecmwf sebagai berikut:

Tabel 3 Nilai Suhu Asimilasi Ecmwf (dalam satuan ${ }^{\circ} \mathrm{C}$ )

\begin{tabular}{lll}
\hline \multirow{2}{*}{ Bulan } & \multicolumn{2}{c}{ Tahun } \\
\cline { 2 - 3 } Januari & 2014 & 2015 \\
Februari & 29,0 & 30,5 \\
Maret & 30,0 & 30,9 \\
April & 31,3 & 30,9 \\
Mei & 29,1 & 31,6 \\
Juni & 30,6 & 29,7 \\
Juli & 30,2 & 29,5 \\
Agustus & 29,4 & 28,3 \\
September & 28,9 & 28,7 \\
Oktober & 30,2 & 29,1 \\
November & 30,9 & 33,2 \\
Desember & 34,2 & 31,2 \\
\hline
\end{tabular}

Dari Tabel 3 diketahui bila suhu tertinggi $34,2{ }^{\circ} \mathrm{C}$ pada bulan Desember tahun 2014 dan suhu terendah sebesar $28,3^{\circ} \mathrm{C}$ pada bulan Juli tahun 2015 . Sedangkan suhu rata-ratanya sebesar $30,2^{\circ} \mathrm{C}$.

Tabel 4. 1 Anomali Suhu Permukaan Laut Aqua MODIS level 3 perairan Surabaya tahun 2014-2015

\begin{tabular}{lcccc}
\hline \multirow{2}{*}{ Bulan } & \multicolumn{2}{c}{ Tahun 2014 } & \multicolumn{2}{c}{ Tahun 2015 } \\
\cline { 2 - 5 } & Suhu & Anomali & Suhu & Anomali \\
\hline Januari & 29,2 & $-1,1$ & 30,6 & 0,3 \\
Februari & 30,0 & $-0,3$ & 30,9 & 0,6 \\
Maret & 31,3 & 1,0 & 30,9 & 0,6
\end{tabular}




\begin{tabular}{lllll} 
April & 29,2 & $-1,1$ & 31,6 & 1,3 \\
Mei & 30,8 & 0,5 & 29,7 & $-0,6$ \\
Juni & 30,2 & 0,0 & 29,5 & $-0,8$ \\
Juli & 29,4 & $-0,9$ & 28,3 & $-2,0$ \\
Agustus & 29,2 & $-1,1$ & 28,7 & $-1,6$ \\
September & 28,9 & $-1,4$ & 29,1 & $-1,1$ \\
Oktober & 30,3 & 0,0 & 29,2 & $-1,1$ \\
November & 31,1 & 0,8 & 33,2 & 2,9 \\
Desember & 34,2 & 3,9 & 31,3 & 1,0 \\
\hline
\end{tabular}

Dapat dilihat pada Tabel 4.4 menunjukkan anomali SPL saat terjadi El Nino (mulai bulan Mei 2015) di perairan Surabaya mengalami penurunan suhu dari rata-rata suhu normalnya yaitu lebih besar dari $0,5^{\circ} \mathrm{C}$.

\section{Tabel 5 Anomali Suhu Permukaan Laut Asimilasi} perairan Surabaya tahun 2014-2015

\begin{tabular}{lcrcc}
\hline \multirow{2}{*}{ Bulan } & \multicolumn{2}{c}{ Tahun 2014 } & \multicolumn{2}{c}{ Tahun 2015 } \\
\cline { 2 - 5 } & Suhu & Anomali & Suhu & Anomali \\
\hline Januari & 29,0 & $-1,2$ & 30,5 & 0,2 \\
Februari & 30,0 & $-0,3$ & 30,9 & 0,7 \\
Maret & 31,3 & 1,1 & 30,9 & 0,6 \\
April & 29,1 & $-1,1$ & 31,6 & 1,4 \\
Mei & 30,6 & 0,3 & 29,7 & $-0,5$ \\
Juni & 30,2 & 0,0 & 29,5 & $-0,8$ \\
Juli & 29,4 & $-0,8$ & 28,3 & $-2,0$ \\
Agustus & 29,2 & $-1,0$ & 28,7 & $-1,6$ \\
September & 28,9 & $-1,3$ & 29,1 & $-1,1$ \\
Oktober & 30,2 & 0,0 & 29,1 & $-1,1$ \\
November & 30,9 & 0,7 & 332 & 2,9 \\
Desember & 34,2 & 4,0 & 31,2 & 1,0 \\
\hline
\end{tabular}

Dapat dilihat pada Tabel 5 menunjukkan anomali SPL saat terjadi El Nino (mulai bulan Mei 2015) di perairan Surabaya mengalami penurunan suhu dari rata-rata suhu normalnya yaitu lebih besar dari $0,5^{\circ} \mathrm{C}$.

Tabel 2 Selisih 2 Data Suhu (dalam satuan ${ }^{\circ} \mathrm{C}$ )

\begin{tabular}{|c|c|c|c|c|c|c|}
\hline \multirow{3}{*}{ Bulan } & \multicolumn{3}{|c|}{ Tahun 2014} & \multicolumn{3}{|c|}{ Tahun 2015} \\
\hline & \multirow[b]{2}{*}{ Suhu 1} & \multicolumn{2}{|c|}{ Suhu } & \multirow{2}{*}{$\begin{array}{l}\text { Suhu } \\
1\end{array}$} & \multirow{2}{*}{$\begin{array}{l}\text { Suhu } \\
2\end{array}$} & \multirow[b]{2}{*}{ selisih } \\
\hline & & 2 & selisih & & & \\
\hline Januari & 29,2 & 29,0 & 0,2 & 30,6 & 30,5 & 0,1 \\
\hline Februari & 30,0 & 30,0 & 0 & 30,9 & 30,9 & 0 \\
\hline Maret & 31,3 & 31,3 & 0 & 30,9 & 30,9 & 0 \\
\hline April & 29,2 & 29,1 & 0,1 & 31,6 & 31,6 & 0 \\
\hline Mei & 30,8 & 30,6 & 0,2 & 29,7 & 29,7 & 0 \\
\hline Juni & 30,2 & 30,2 & 0 & 29,5 & 29,5 & 0 \\
\hline Juli & 29,4 & 29,4 & 0 & 28,3 & 28,3 & 0 \\
\hline Agustus & 29,2 & 29,2 & 0 & 28,7 & 28,7 & 0 \\
\hline
\end{tabular}


sebesar $34,2^{\circ} \mathrm{C}, 33,2^{\circ} \mathrm{C}$, dan $31,6^{\circ} \mathrm{C}$ pada Desember 2014, November 2015, dan April 2015. Sedangkan nilai SPL terendah sebesar $28,3^{\circ} \mathrm{C}, 28,7^{\circ} \mathrm{C}$ dan $28,9^{\circ} \mathrm{C}$ pada Juli 2015, Agustus 2015, dan September 2014.

Hasil Pengolahan Data

Hasil pengolahan data pasang surut berupa nilai muka air laut rata-rata (MSL) untuk lokasi Surabaya tahun 2014-2015 seperti terlihat pada tabel berikut ini:

Tabel 3 Nilai MSL Surabaya (dalam satuan cm)

\begin{tabular}{ccc}
\hline \multirow{2}{*}{ Bulan } & \multicolumn{2}{c}{ Tahun } \\
\cline { 2 - 3 } & 2014 & 2015 \\
\hline Januari & 122,09 & 117,79 \\
Februari & 105,12 & 105,39 \\
Maret & 104,65 & 106,54 \\
April & 109,16 & 110,66 \\
Mei & 117,80 & 115,90 \\
Juni & 117,30 & 112,15 \\
Juli & 114,99 & 108,09 \\
Agustus & 110,40 & 105,34 \\
September & 104,25 & 101,15 \\
Oktober & 103,87 & 101,85 \\
November & 108,13 & 103,92 \\
Desember & 113,69 & 103,79 \\
\hline
\end{tabular}

Nilai Mean Sea Level untuk lokasi pengamatan Surabaya dari tahun 2014 hingga 2015 bervariasi. Nilai MSL terendah 101,15 cm di atas nol rambu pada September 2015 dan nilai MSL tertinggi 122,09 cm di atas nol rambu pada Januari 2014. Rentang variasi nilai MSL terendah-tertinggi sebesar $20,94 \mathrm{~cm}$.

\section{Analisa Komponen Harmonik Pasang Surut}

Hasil pengolahan komponen harmonik pasang surut berupa nilai amplitudo untuk lokasi Surabaya tahun 2014 dan tahun 2015, memiliki amplitudo konstanta harmonik pasang surut $\mathrm{M} 2$ diperoleh rata-rata sebesar $39,32 \mathrm{~cm}$. Fluktuasi nilai konstanta harmonik pasang surut $\mathrm{M} 2$ ini adalah sebesar $3,52 \mathrm{~cm}$ dengan amplitudo terkecil sebesar 37,79 cm dan terbesar 41,31 cm. Amplitudo terkecil diperoleh pada perhitungan data bulan Desember 2014, sedangkan yang terbesar diperoleh pada Bulan April 2015.

Amplitudo konstanta harmonik pasang surut S2 diperoleh rata-rata sebesar $22,88 \mathrm{~cm}$. Fluktuasi nilai konstanta harmonik pasang surut S2 ini adalah sebesar $17,07 \mathrm{~cm}$ dengan amplitudo terkecil sebesar $17,53 \mathrm{~cm}$ dan terbesar $34,61 \mathrm{~cm}$. Amplitudo terkecil diperoleh pada perhitungan data bulan Agustus 2014, sedangkan yang terbesar diperoleh pada Bulan Januari 2014.

Amplitudo konstanta harmonik pasang surut N2 diperoleh rata-rata sebesar $7,79 \mathrm{~cm}$. Fluktuasi nilai konstanta harmonik pasang surut $\mathrm{M} 2$ ini adalah sebesar 7,94 cm dengan amplitudo terkecil sebesar $5,30 \mathrm{~cm}$ dan terbesar $13,24 \mathrm{~cm}$. Amplitudo terkecil diperoleh pada perhitungan data bulan Mei 2014, sedangkan yang terbesar diperoleh pada Bulan Januari 2014.

Amplitudo konstanta harmonik pasang surut K2 diperoleh rata-rata sebesar $7,16 \mathrm{~cm}$. Fluktuasi nilai konstanta harmonik pasang surut $\mathrm{K} 2$ ini adalah sebesar 47,05 cm dengan amplitudo terkecil sebesar 2,46 cm dan terbesar 49,51 cm. Amplitudo terkecil diperoleh pada perhitungan data bulan Oktober 2015, sedangkan yang terbesar diperoleh pada Bulan Januari 2014.

Amplitudo konstanta harmonik pasang surut K1 diperoleh rata-rata sebesar $43,73 \mathrm{~cm}$. Fluktuasi nilai konstanta harmonik pasang surut K2 ini adalah sebesar $39,81 \mathrm{~cm}$ dengan amplitudo terkecil sebesar $32,97 \mathrm{~cm}$ dan terbesar $72,77 \mathrm{~cm}$. Amplitudo terkecil diperoleh pada perhitungan data bulan Desember 2015, sedangkan yang terbesar diperoleh pada Bulan Januari 2014.

Amplitudo konstanta harmonik pasang surut $\mathrm{O} 1$ diperoleh rata-rata sebesar $21,9 \mathrm{~cm}$. Fluktuasi nilai konstanta harmonik pasang surut $\mathrm{O} 1 \mathrm{ini}$ adalah sebesar $3,79 \mathrm{~cm}$ dengan amplitudo terkecil sebesar 19,91 cm dan terbesar 23,70 cm. Amplitudo terkecil diperoleh pada perhitungan data bulan Februari 2015, sedangkan yang terbesar diperoleh pada Bulan Juli 2014.

Amplitudo konstanta harmonik pasang surut P1 diperoleh rata-rata sebesar $16,24 \mathrm{~cm}$. Fluktuasi nilai konstanta harmonik pasang surut P1 ini adalah sebesar $25,75 \mathrm{~cm}$ dengan amplitudo terkecil sebesar $3,68 \mathrm{~cm}$ dan terbesar 29,43 cm. Amplitudo terkecil diperoleh pada perhitungan data bulan Januari 2015, sedangkan yang terbesar diperoleh pada Bulan Januari 2014.

Amplitudo konstanta harmonik pasang surut M4 diperoleh rata-rata sebesar $1,94 \mathrm{~cm}$. Fluktuasi nilai konstanta harmonik pasang surut M4 ini adalah sebesar $1,87 \mathrm{~cm}$ dengan amplitudo terkecil sebesar $1,01 \mathrm{~cm}$ dan terbesar $2,89 \mathrm{~cm}$. Amplitudo terkecil diperoleh pada perhitungan data bulan September 2014, sedangkan yang terbesar diperoleh pada Bulan Januari 2014.

Amplitudo konstanta harmonik pasang surut MS4 diperoleh rata-rata sebesar $2,45 \mathrm{~cm}$. Fluktuasi nilai konstanta harmonik pasang surut MS4 ini adalah sebesar 2,95 cm dengan amplitudo terkecil sebesar $0,90 \mathrm{~cm}$ dan terbesar $3,87 \mathrm{~cm}$. Amplitudo terkecil diperoleh pada perhitungan data bulan Mei 2014, sedangkan yang terbesar diperoleh pada Bulan Februari 2015.

Berdasarkan Gambar 6 dan 7 hasil perhitungan amplitudo konstanta harmonik pasang surut menunjukkan konstanta ampitudo K1 memiliki nilai terbesar. Hal ini sesuai dengan teori Pinet pada Rampengan (2009), konstanta harmonik K1 sebagai komponen pasang surut bulan utama, umumnya 
memiliki amplitudo lebih besar daripada konstanta amplitudo lainnya.

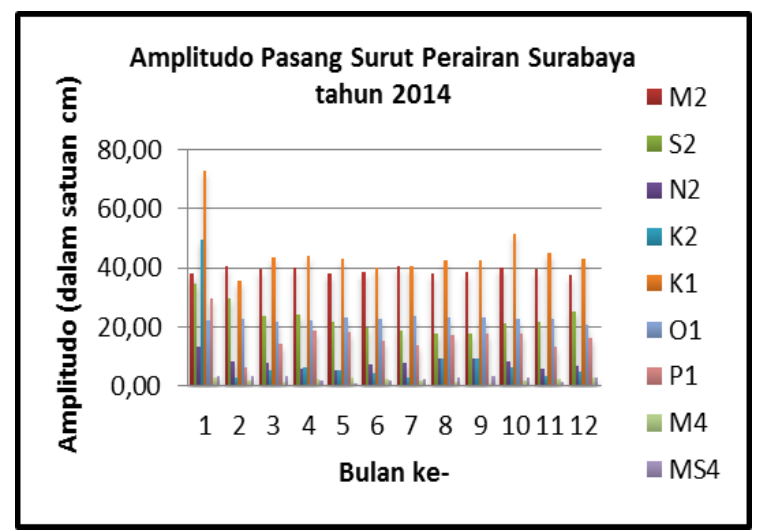

Gambar 6 Histogram amplitudo pasang surut Surabaya tahun 2014

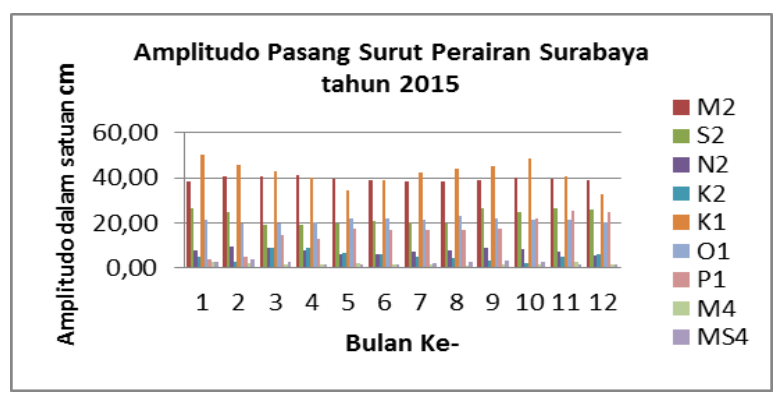

Gambar 7 Histogram Amplitudo Pasang Surut Surabaya tahun 2015

Grafik Mean Sea level

Kemudian dari nilai muka air laut (MSL), selanjutnya data hasil pengolahan dijadikan grafik dengan perangkat lunak Microsoft excel. Adapun pembuatan grafik dilakukan untuk melihat secara grafis perubahan kedudukan muka air laut. Berikut ini pada Gambar 8 grafik Mean Sea Level (MSL) Surabaya:

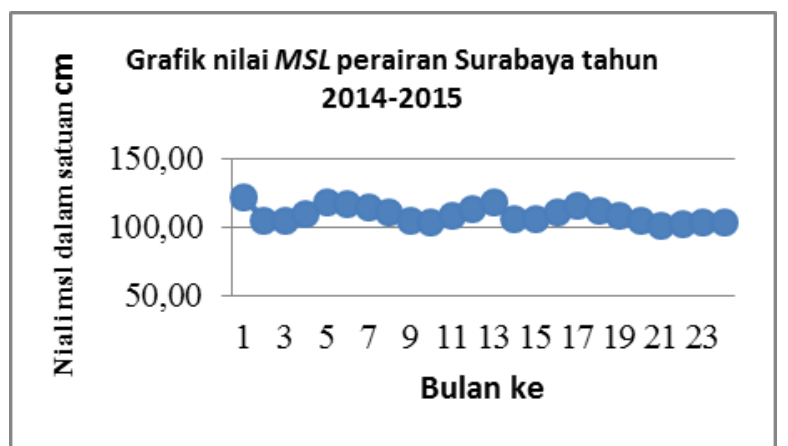

Gambar 8 Grafik MSL perairan Surabaya tahun 20142015 (dalam satuan $\mathrm{cm}$ )

Grafik nilai MSL Surabaya tahun 2014-2015 menunjukkan bahwa nilai MSL Surabaya fluktuatif. Hal ini dapat dilihat pada nilai MSL tertinggi sebesar 122,09 $\mathrm{cm}, 117,80 \mathrm{~cm}$, dan $117,79 \mathrm{~cm}$ pada Januari 2014, Mei 2014, dan Januari 2015. Sedangkan nilai MSL terendah sebesar $101,15 \mathrm{~cm}, 101,85 \mathrm{~cm}$ dan $103,79 \mathrm{~cm}$ pada September 2015, Oktober 2015, dan Desember 2015. Analisa Hasil Mean Sea Level

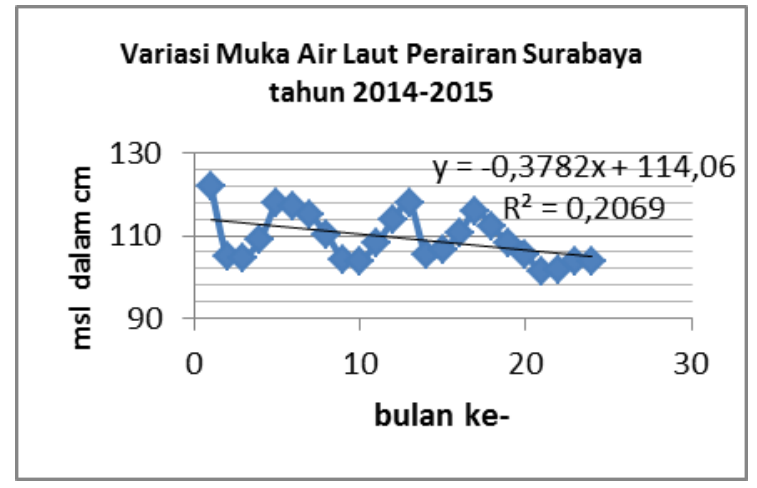

Gambar 9 Tren MSL Surabaya

Diketahui persamaan regresi linier untuk tren Surabaya adalah $y=114 \cdot 1-0,3782 x$. sesuai dengan persamaan tersebut nilai $x$ dapat disubtitusikan dengan nilai bulan minimal dan bulan maksimal dari data yang ada. Dalam hal ini variabel $x$ Surabaya minimal 1 bulan dan maksimal 24 bulan. Kemudian disubtitusikan nilai $x=1$ dan $\mathrm{x}=24$ kedalam persamaaan sehingga diperoleh:

$\mathrm{X}=1$ bulan $\rightarrow$ y awal $=113,722 \mathrm{~cm}$ dan

$\mathrm{X}=24$ bulan $\rightarrow$ y akhir $=105,028 \mathrm{~cm}$

Untuk mencari nilai tren kenaikan pertahun makadilakukan perhitungan seperti rumusan dibawah ini:

Tren $=(Y$ akhir-Yawal $) /$ jumlah tahun

Sehingga didapatkan nilai tren MSL Surabaya= $-4,347 \mathrm{~cm} /$ tahun. Pada pengukuran tingkat kesesuaian model regresi yang digunakan adalah dengan melihat $\mathrm{R}$ square (2) hasil permodelan dengan harga pendekatan R2 adalah skala 0-1. Artinya semakin mendekati 1 maka nilai pemodelan sesuai. Berdasarkan regresi linier didapatkan hasil penurunan MSL Surabaya sebesar 4,347 cm per tahun dan R2 mencapai 0,2069 atau 20,69\%. Permodelan ini belum mendekati nilai 1 artinya permodelan ini memiliki kesesuaian mencapai 0,2069. Hal ini disebabkan banyak data pengamatan pasang surut yang kosong, sehingga dilakukan interpolasi, sehingga hasil MSL dan permodelan yang digunakan belum maksimal. 
Hubungan antara Pasang Surut Air Laut dengan Fenomena Iklim

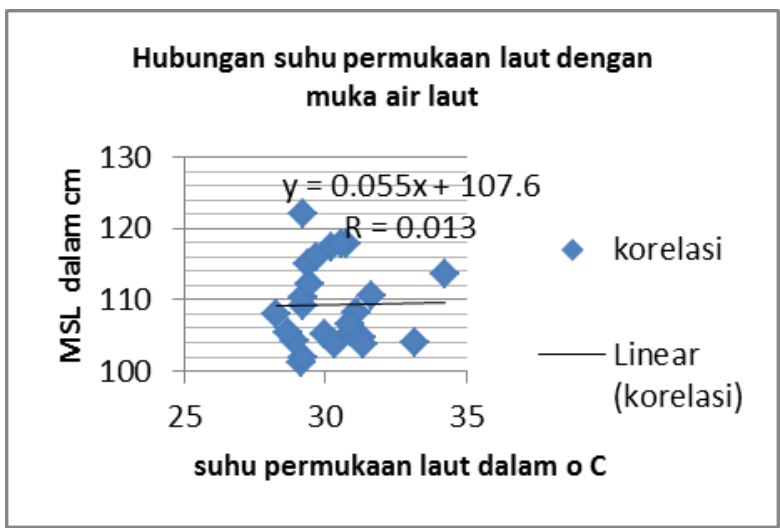

Gambar 10 Hubungan SPL dengan MSL

Diketahui persamaan regresi linier untuk hubungan MSL dengan SPL adalah $\mathrm{y}=$ $107,7+0,055 x$. sesuai dengan persamaan tersebut nilai $x$ dapat disubtitusikan dengan nilai bulan minimal dan bulan maksimal dari data yang ada. Untuk mengukur tingkat kesesuaian model regresi yang digunakan adalah dengan melihat $\mathrm{R}$ Square $\left(R^{2}\right)$ hasil permodelan dengan harga pendekatan $\mathrm{R}^{2}$ adalah skala 0-1. Artinya semakin mendekati 1 maka nilai pemodelan sesuai. Berdasarkan regresi linier didapatkan hasil tren MSL berdasarkan SPL Surabaya sebesar 0,16 cm per tahun dan R2 mencapai 0,013 atau 1,3\%. Permodelan ini belum mendekati nilai 1 artinya permodelan ini memiliki kesesuain mencapai 0,013. Hal ini disebabkan suhu hanya sedikit mempengaruhi perubahan muka air laut, serta masih dibutuhkan variabel lain yang berhubungan dan memiliki pengaruh yang lebih kuat seperti curah hujan dan tekanan udara. Sehingga hasil permodelan yang digunakan belum maksimal.

Akan tetapi dari data variasi muka air laut perairan Surabaya yang tersedia, terdapat satu waktu yang menandai terjadinya El Nino. Seperti yang dilihat pada Gambar 9, variasi muka air laut pada bulan Mei hingga Desember tahun 2015 menandakan kecenderungan penurunan yang cukup signifikan.

\section{KESIMPULAN}

Adapun beberapa hal yang dapat disimpulkan dari penelitian ini adalah:

1. Hasil nilai muka air laut rata-rata perairan Surabaya tertinggi sebesar $122,09 \mathrm{~cm}$ pada bulan Januari 2014 dan nilai terrendah sebesar $103,79 \mathrm{~cm}$ pada bulan Desember tahun 2015 seperti gambar 5. Hasil nilai suhu permukaan laut perairan Surabaya tertinggi $34,20{ }^{\circ} \mathrm{C}$ dan nilai terrendah sebesar $28,28^{\circ} \mathrm{C}$.

2. Penurunan $M S L$ di Perairan Surabaya selama terjadi El Nino mengikuti persamaan linier dengan persamaan $Y=114.1-0.3782 x$ $\left(R^{2}=0,2069\right)$ dengan penurunan $M S L$ sebesar 4,347 cm per tahun. Hubungan tren $M S L$ dengan SPL di Perairan Surabaya mengikuti persamaan linier dengan persamaan $Y=$ $107,7+0,055 \times(R=0,013)$.

\section{UCAPAN TERIMA KASIH}

Kami sampaikan terima kasih kepada kepada Departemen Geomatika ITS yang telah memberikan dukungan administrasi dan pendanaan sehingga penelitian ini dapat berjalan dengan baik dan lancar.

\section{DAFTAR PUSTAKA}

Supari, M. (2015). Sejarah Dampak El Nino Indonesia. Badan Meteorologi, Klimatologi dan Geofisika.

Linggasari, Y. (2015). El Nino Menguat, Kemarau Diperkirakan Hingga November. CNN Indonesia.

Abdullah, M. H., Mahmud, M. R., \& Amat, N. A. (2015). Variations of Sea Level and Tidal Behavior during El Nino/ La Nina: An Example of Malaysian Coastline. Junal Teknologi , 107-118.

Badan Informasi Geospasial. (2014). Peta Inageoportal. Http://www.tanahair.indonesia.go.id. (diakses tanggal 26 Desember, 2015)

Ongkosongo. 1989. Pasang Surut. Jakarta: LIPI.

Riyadi. (2013). Pengamatan Pasang Surut Air Laut di Pelabuhan Bitung Sebagai Prediksi Awal Terjadi El Nino dan La Nina. Kasie Data dan Informasi Stasiun Geofisika Manado. 